\title{
INOVASI PELAYANAN "LARAKU NYATA" BAGI PENYANDANG DISABILITAS DI DINAS KEPENDUDUKAN DAN CATATAN SIPIL KABUPATEN BULUKUMBA
}

\author{
Bau Sri Sudarni ${ }^{1}$, Ihyani Malik ${ }^{2}$, Haerana ${ }^{3}$ \\ 1,2,3 Universitas Muhammadiyah Makassar, Indonesia \\ srisudarnibau@gmail.com
}

\begin{abstract}
This study purposed to explain the "Laraku Real" Service Innovation for Persons with Disabilities at the Population and Civil Registration Office of Bulukumba Regency. This study used qualitative research with data collection techniques used interview instruments, observation and literature study. The number of informants in this study were 4 people. The data was analyzed interactively which took place continuously until the data obtained is saturated. The results showed that during the implementation of the "Laraku Real" service innovation for people with disabilities at the Population and Civil Registration Office of Bulukumba Regency, it had many significant impacts for people with disabilities. The ease of completing population data, social assistance, health was obtained by persons with disabilities besides this innovation had been able to be implemented in accordance with Operational Standards and deserves to be called a Public Service Innovation with the fulfillment of the characteristics/attributes that must be possessed by every service innovation established public.
\end{abstract}

Keywords: Innovation, Services, Persons with Disabilities.

\begin{abstract}
Abstrak
Penelitian ini bertujuan untuk menjelaskan Inovasi Pelayanan "Laraku Nyata" bagi Penyandang Disabilitas di Dinas Kependudukan dan Pencatatan Sipil Kabupaten Bulukumba. Jenis penelitian ini adalah penelitian Kualitatif dengan teknik pengumpulan data yang digunakan yaitu instrumen wawancara, observasi dan studi kepustakaan. Adapun jumlah informan dalam penelitian ini adalah 4 orang. Data tersebut dianalisis secara interaktif yang berlangsung secara terus menerus sampai tuntas hingga data yang didapat sudah jenuh. Hasil penelitian menunjukkan bahwa selama pelaksanaan inovasi pelayanan "Laraku Nyata" bagi penyandang disabilitas di Dinas Kependudukan dan Pencatatan Sipil Kabupaten Bulukumba telah memberikan banyak dampak yang signifikan bagi penyandang disabilitas. Kemudahan dalam melengkapi data-data kependudukan, bantuan-bantuan sosial, kesehatan didapatkan oleh penyandang disabilitas selain itu Inovasi ini telah mampu dilaksanakan sesuai dengan Standar Operasional dan layak dikatakan sebagai Inovasi Pelayanan Publik dengan terpenuhinya ciri-ciri/atribut yang harus dimiliki oleh setiap inovasi pelayanan publik yang dibentuk.
\end{abstract}

Kata Kunci: Inovasi, Pelayanan, Penyandang Disabilitas.

\section{PENDAHULUAN}

Inovasi adalah sebuah penemuan yang berbeda atau baru dengan sesuatu yang pernah ada sebelumnya. Seseorang yang inovatif akan selalu berupaya melakukan perbaikan, memperbaiki hal-hal yang sudah ada dan akan senantiasa menciptakan sesuatu yang baru. Inovasi dibidang pelayanan publik merupakan suatu ide kreatifteknologi atau menciptakan terobosan atau penyederhanaan dibidang aturan, bidang pendekatan, prosedur dan metode, maupun struktur organisasi pelayanan yang manfaatnya mempunyai nilai tambah yang baik dari segi kuantitas maupun kualitas pelayanan. Setijaningrum dalam Cahyaningrum dan Nugroho (2019) mengemukakan inovasi pelayanan publik merupakan kreativitas atau ciptaan yang baru dalam pelayanan publik.

Pelayanan publik saat ini telah menjadi isu sentral dalam pembangunan di Indonesia. Segala pelayanan publik memang harus semakin 
efektif dan efesien. Memberikan pelayanan terbaik adalah sesuatu yang tak asing lagi, akan tetapi sudah menjadi kebutuhan yang layak dipenuhi untuk mengikuti kecepatan perkembangan kemajuan teknologi. Secara teoritis, pada dasarnya tujuan pelayanan publik adalah memuaskan masyarakat (Sinambela, 2010). Dalam pelaksanaan pelayanan publik harus sesuai dengan standar pelayanan sebagai bentuk pedoman penyelenggaraan pelayanan serta acuan penilaian kualitas pelayanan kepada masyarakat demi mewujudkan pelayanan yang berkualitas. Jika kenyataan lebih dari yang diharapkan, maka layanan dapat dikatakan bermutu sedangkan jika kenyataan kurang dari yang diharapkan, maka pelayanan dikatakan tidak bermutu, dan apabila kenyataan sama dengan harapan, maka layanan disebut memuaskan (Lupiyoadi, 2001). Undang-undang Pelayanan Publik (secara resmi bernama Undang-Undang Nomor 25 Tahun 2009 tentang Pelayanan Publik) adalah undang-undang yang mengatur tentang prinsip-prinsip pemerintahan yang baik yang merupakan efektivitas fungsifungsi pemerintahan itu sendiri. Pelayanan publik dilakukan oleh pemerintahan dapat memperkuat demokrasi dan hak asasi manusia, mempromosikan kemakmuran ekonomi, kohesi social, mengurangi kemiskinan, meningkatkan perlindungan lingkungan, bijak dalam pemanfaatan sumber daya alam, memperdalam kepercayaan pada pemerintahan dan administrasi publik.

Pelayanan publik dengan kata lain merupakan pelayanan kepada seluruh elemen masyarakat. Realitas yang ada tentang masyarakat yang mendiami suatu negara, daerah tentunya memiliki perbedaan dan yang paling mencolok adalah kondisi fisik masyarakat. Kondisi fisik yang kurang sempurna atau sering disebut dengan difable menjadi sesuatu yang harus diperhatikan dalam melaksanakan pelayanan publik. Dalam ruang pelayanan publik orang-orang yang memiliki keterbatasan itu perlu mendapatkan perlakuan khusus agar pelayanan yang diciptakan untuk seluruh elemen masyarakat dapat terlaksana sesuai dengan tujuan awalnya.

Mengenai pelayanan publik difable atau penyandang disabilitas dalam undang-undang pun telah diatur yaitu pasal 18 ayat (1) UndangUndang Nomor 8 Tahun 2016 tentang Penyandang Disabilitas menyatakan bahwa hak aksebilitas bagi penyandang disabilitas meliputi hak mendapatkan aksebilitas untuk memanfaatkan fasilitas publik. Selanjutnya dalam pasal 19 disebutkan bahwa penyandang disabilitas mempunya hak pelayanan publik meliputi hak memperoleh akomodasi yang layak selama pelayanan publik secara optimal, wajar, bermartabat tanpa diskriminasi, pendampingan, penerjemahan, dan penyediaan fasilitas yang dapat diakses di tempat layanan publik tanpa biaya tambahan. Penyandang disabilitas sebagai salah satu penyandang kesejahteraan social sangat perlu mendapat perhatian. Secara tidak langsung mereka akan mengalami kesulitan dalam melakukan aktivitas dibandikan dengan orang yang normal secara fisik. Begitupun dalam akses informasi dalam melakukan rehabilitasi. Oleh karena itu penyandang disabilitas perlu mendapatkan perhatian khusus dengan menciptakan inovasi-inovasi disetiap instansi Pemerintah setempat. Dinas Kependudukan dan Pecatatan Sipil merupakan instansi pemerintahan yang bertugas untuk memberikan peelayanan dalam bidang administrasi kependudukan. Jika berbicara tentang kependudukan maka erat kaitannya dengan pelayanan kepada masyarakat. Sebagai instansi yang berperan aktif memberikan pelayanan kepada masyarakat, Dinas Kependudukan dan Pencatatan Sipil harus memberikan pelayanan yang baik sesuai dengan standar operasional yang berlaku. Pelayanan bagi penyandang disabilitas di Kabupaten Bulukumba telah di atur pula pada Peraturan Daerah Kabupaten Bulukumba Nomor 2 Tahun 2018 tentang Perlindungan dan Pelayanan Penyandang Disabilitas Pasal 5 yaitu kewajiban perlindungan dan pelayanan penyandang disabilitas merupakan tanggungjawab bersama antara Pemerintah Daerah dan Masyarakat. Dinas Kependudukan dan Pencatatan Sipil Kabupaten Bulukumba, untuk merespon keluhan-keluhan masyarakat mengenai pemerataan pelayanan terkhusus bagi penyandang disabilitas, maka Dinas Kependudukan dan Pencatatan Sipil membentuk inovasi baru dalam standar pelayanannya yaitu Laraku Nyata.

Laraku Nyata adalah istilah dalam inovasi pelayanan publik administrasi kependudukan yang dibuat oleh Dinas Kependudukan dan Pencatatan Sipil Kabupaten Bulukumba dan merupakan singkatan dari Pelayanan Administrasi Kependudukan bagi Penyandang Disabilitas. 
Inti dari "Laraku Nyata" ini berfokus pada pelayanan bagi penyandang disabilitas yang ada di Kabupaten Bulukumba. Pelayanan ini berupa kemudahan yang diberikan kepada penyandang disabilitas untuk melakukan pengurusan penerbitan e-KTP, Akte Kelahiran dan lain-lain. Bentuk pelayanan Laraku Nyata itu mencakup pendataan, penjemputan, dan pelayanan perekaman biometric KTP-el.

Kabupaten Bulukumba sendiri dikutip dari JIPP.sulselprov.go.id terdapat 1.018 orang jumlah penduduk yang termasuk dalam penyandang disabiilitas dan banyak diantaranya yang belum memiliki dokumen-dokumen kependudukan.

Saat diberlakukannya inovasi laraku nyata memberikan dampak yang baik yaitu peningkatan kepemilikan dokumen kependudukan bagi penyandang disabiilitas di Kabupaten Bulukumba dengan peningkatan 223 orang pada awal tahun 2018. Sedangkan data yang dikutip dari rakyatku.com, terdapat 1.223 penyadang disabilitas di Kabupaten Bulukumba per tanggal 28 november 2019 yang membutuhkan perhatian khusus. Inovasi yang telah dilakukan oleh Dinas Kependudukan dan Pencatatan Sipil Kabupaten Bulukumba dalam hal ini "Laraku nyata" bagi penyandang disabilitas telah membuahkan hasil dan data terakhir yang dipublikasikan oleh Dinas Kependudukan dan Pecatatan Sipil di awal Tahun 2018 dan mengalami peningkatan.

Menurut Rahmawati dan Suryawaty (2017) pelayanan publik merupakan bentuk atau rangkaian kegiatan dalam rangka untuk memenuhi kebutuhan dalam pelayanan yang sesuai dengan peraturan perundang-undangan bagi setiap warga negara, atas barang, jasa dan atau pelayanan administratif lainnya.

Agung Kurniawan dalam Purwanti (2018) menyatakan pendapatnya bahwa pelayanan publik adalah pemberian pelayanan atau melayani keperluan orang lain atau masyarakat yang memiliki kepentingan terhadap suatu organisasi yang sesuai dengan aturan pokok dan tata cara yang ditetapkan.

Sedangkan menurut UU No. 25 Tahun 2009 tentang Pelayanan Publik yang dikutip dalam Purwanti (2018) pelayanan publik diuraikan sebagai kegiatan ataupun rangkaian kegiatan dalam rangka pemenuhan kebutuhan pelayanan yang sesuai dengan peraturan perundang-undangan bagi setiap warga negara dan penduduk atas barang, jasa, dan pelayanan administratif yang disediakan oleh penyelenggara atau yang menerapkan sistem pelayanan publik. Berkaitan dengan implementasi kebijakan publik, teori dan model implementasi sangatlah berkaitan. Teori sebagai abstraksi objek atau gagasan, sedangkan model yaitu perwujudan dari teori tersebut.

Inovasi menurut Galbraith dan Schon dalam Rahmawati dan Suryawaty (2017) suatu proses dari penggunaan teknologi baru ke dalam suatu produk sehingga produk tersebut memperoleh nilai tambah dari sebelumnya. Inovasi adalah memperkenalkan ide atau gagasan baru, barang baru, pelayanan baru, serta berbagai cara baru yang lebih bermanfaat. Sedangkan Menurut Rogers dalam Atthahara (2018) inovasi adalah sebuah ide, praktik atau objek yang dianggap baru oleh individu pada satu unit tertentu.

Menurut Amabile et aL dalam Rahmawati dan Suryawaty (2017) inovasi yang berhubungan dengan kreatifitas adalah inovasi atau innovation yang berasal dari kata innovate yang memiliki arti yaitu membuat perubahan atau memperkenalkan sesuatu yang baru.

Dalam penerapannya inovasi memiliki beberapa atribut atau bagian yang melekat di dalam inovasi. Menurut Rogers dalam Basri (2018) ciri-ciri inovasi itu terdiri dari: 1) Relative Advantage atau keuntungan relatif, merupakan sebuah inovasi yang harus memiliki keuntungan dan nilai yang lebih dibandingkan dengan inovasi yang telah dilakukan sebelumnya. Selalu ada pembaruan dalam berinovasi yang menjadi ciri untuk membedakannya dengan yang lain. 2) Compability atau kesesuaian, inovasi mempunyai sifat kompatibel dan sesuai dengan inovasi digantinya. Hal ini dimaksudkan agar inovasi yang lama tidak serta merta dibuang begitu saja, karena faktor biaya yang digunakan tidak sedikit, serta inovasi yang lama menjadi bagian dalam proses transisi ke inovasi terbaru. 3) Complexity atau kerumitan, dengan sifatnya yang baru, maka inovasi memiliki tingkat kerumitan yang kemudian bisa menjadi hasil lebih tinggi dibandingkan dengan inovasi yang telah dilaksanakan sebelumnya. 4) Triability atau kemungkinan dicoba, merupakan inovasi yang hanya bisa diterima apabila teruji dan mampu terbukti memiliki keuntungan atau nilai lebih yang dihasilkan dibandingkan dengan inovasi lama. Sehingga produk inovasi harus 
melewati fase uji coba dimana setiap orang atau pihak memiliki kesempatan untuk menguji kualitas dari setiap inovasi yang dibuat. 5) Observability (Kemudahan diamati), berarti untuk menggambarkan bagaimana inovasi baru diciptakan bisa menghasilkan dampak lebih baik dan berjalan sesuai dengan harapan instansi selaku pencipta inovasi. Sebuah inovasi harus dapat diamati dari segi bagaimana ia bekerja dan menghasilkan sesuatu yang lebih baik ke depannya untuk keperluan pelayanan publik yang tepat pada sasaran.

\section{METODE}

Jenis penelitian yang digunakan adalah penelitian kualitatif. Penelitian ini bertujuan untuk mengetahui gambaran inovasi pelayanan publik laraku nyata di kantor Dinas Kependudukan dan Pencatatan Sipil Kabupaten Bulukumba.

Jenis penelitian yang digunakan penelitian kualitatif dengan tipe pendekatan deskriptif. Penentuan Informan peneliti menggunakan metode Purposive Sampling dimana teknik menentukan orang yang mengerti dan terlibat langsung ke dalam permasalahan penelitian. Data penelitian ini dikumpul melalui observasi, wawancara, studi dokumentasi. Teknik analisis data yang dilakukan adalah reduksi data, penyajian data dan kesimpulan. Pengabsahan data dilakukan dengan perpanjangan pengamatan, triangulasi dan mengadakan member cek.

\section{HASIL DAN PEMBAHASAN}

Kantor Dinas Kependudukan dan Pencatatan Sipil Kabupaten Bulukumba merupakan kantor Pemerintah yang memberikan pelayanan administrasi kependudukan yang tercantum pada pasal $1 \mathrm{UU}$ No. 24 tahun 2013 tentang administrasi kependudukan adalah rangkaian kegiatan dalam penerbitan dokumen dan data kependudukan melalui pendaftaran penduduk, pencatatan sipil, pengelolaan informasi administrasi kependudukan serta pendayagunaan hasil untuk pelayanan publik dan sektor lain.

Ada beberapa fungsi Dinas Kependudukan dan Pencatatan Sipil yaitu melakukukan penyusunan rencana pembangunan dan pengembangan kegiatan pendaftaran dan pencatatan penduduk, melakukan pembinaan umum, pemberian Nomor Induk Kependudukan (NIK), pendaftaran dan penerbitan Kartu Keluarga, pendaftaran dan penerbitan Kartu Tanda Penduduk (KTP), pencatatan dan penerbitan Akta-akta catatan, pencatatan mutasi penduduk, pengelolaan data penduduk, penyelenggaraan penyuluhan, dan pelaksanaan pembinaan pengolahan cabang dinas dan unit pelaksanaan teknis.

Dinas Kependudukan dan Pencatatan Sipil membangun visi pelayanan administrasi kependudukan dengan isu strategis yang bertumpu pada terwujudnya pelayanan prima kepada masyarakat. Adapun Visi dari Dinas Kependudukan dan Pencatatan Sipil Kabupaten Bulukumba adalah Terwujudnya Pelayanan Prima Dibidang Administrasi Kependudukan dan Pencatatan Sipil yang Berbasis Teknologi Informasi. Kemudian Misi dari Dinas Kependudukan dan Pencatatan Sipil Kabupaten Bulukumba yaitu Meningkatkan Kualitas Pelayanan Aministrasi Kependudukan dan Pencatatan Sipil yang Berpedoman pada Prinsip-Prinsip Pelayanan Prima.

Adapun uraian tugas Dinas Kependudukan dan Pencatatan Sipil Kabupaten Bulukumba yaitu mengkoordinasikan perumusan rencana strategi di Dinas Kependudukan dan Pencatatan Sipil, mengkoordinasikan perumusan kebijakan agar terciptanya sinkronasi dan integritasi kebijakan pemerintah dalam kerja dan kewenangan Dinas Kependudukan dan Pencatatan Sipil, menyelenggarakan Kependudukan dan Pencatatan Sipil, melaksanakan pengendalian, penempatan dan pembinaan kepegawaian lingkup Dinas Kependudukan dan Pencatatan Sipil, mengendalikan pengelolaan keuangan Dinas Kependudukan dan Pencatatan Sipil, menyelenggarakan urusan umum Dinas Kependudukan dan Pencatatan Sipil, melakukan pemantauan dan evaluasi secara berkala pelaksanaan kebijakan pemerintah daerah lingkup Dinas Kependudukan dan Pencatatan Sipil, mengkonsultasikan dan mengkoordinasikan program dan kegiatan dengan pemerintah pusat dan provinsi dalam rangka terciptanya keselarasan program dan kegiatan antar tingkat pemerintah dalam lingkup kerja dan kewenangan Dinas Kependudukan dan Pencatatan Sipil, mendistribusikan tugas dan memberi petunjuk pelaksanaan tugas kepada bawahan, memantau dan mengevaluasi serta menilai pelaksanaan tugas bawahan, 
melaporkan hasil pelaksanaan tugas Dinas Kependudukan dan Pencatatan Sipil kepada Bupati melalui sekretaris daerah, melaksanaan tugas kedinasan lain yang diperintahkan oleh atasan sesuai dengan bidang tugasnya

Untuk melaksanakan tugas tersebut Dinas Kependudukan dan Pencatatan Sipil kabupaten Bulukumba mempunyai fungsi sebagai yaitu: Pertama, perumusan kebijakan teknis di bidang kependudukan dan Pencatatan Sipil. Kedua, Pemberian dukungan atas penyelenggaraan pemerintah daerah di bidang kependudukan dan pencatatan sipil. Ketiga, Pembinaan dan pelaksanaan tugas di bidang kependudukan dan pencatatan sipil

Dari keseluruhan metode yang digunakan diperoleh hasil berdasarkan indikator pelaksanaan inovasi yang diambil dari teori Rogers mengenai atribut atau ciri-ciri inovasi pelayanan publik yang baik. Teori tersebut mencakup lima indikator yang terdiri dari:

\section{Relative Adventage (keuntungan relatif)}

Menurut Rogers Relative Adventage (keuntungan relatif) merupakan sebuah inovasi yang harus memiliki keuntungan dan nilai yang lebih dibandingkan dengan inovasi yang telah dilakukan sebelumnya. Keuntungan relatif yang dimaksud dalam penelitian ini adalah inovasi "Laraku Nyata" bagi pelayanan penyandang disabilitas di Dinas Kependudukan dan Pencatatan Sipil Kabupaten Bulukumba yaitu bahwa sebagai inovasi pelayanaan publik yang baru maka perlu dilihat dari keuntungan dan dampak positif yang diperoleh dari inovasi tersebut. Setiap inovasi yang dibentuk memang harus memiliki unsur dari keuntungan relatif. Dari hasil wawancara yang diperoleh dapat dilihat bahwa inovasi layanan "Laraku Nyata" merupakan inovasi yang memiliki pengaruh yang sangat besar bagi penyandang disabilitas itu sendiri. Karena dengan adanya inovasi tersebut para penyandang disabilitas dapat dengan mudah mendapatkan pelayanan terkait data kependudukan.

Hal itu memiliki banyak keuntungan dan dampak positf kepada kedua belah pihak, baik untuk Dinas Kependudukan dan Pencatatan Sipil Kabupaten Bulukumba berupa keakuratan data dan bagi penyandang disabilitas berupa pelayanan administrasi kependudukan yang mudah dan bantuan-bantuan sosial lainnya. Sehingga inovasi pelayanan "Laraku Nyata" telah memiliki keuntungan dan memberikan dampak yang positif dalam pengaplikasiannya.

Data-data sekunder yang didapatkan menunjukkan peningkatan kepemilikan data kependudukan bagi penyandang disabilitas yaitu pada tahun 2016-2018 jumlah penduduk penyandang disabilitas se-Kabupaten Bulukumba berjumlah 85, 95, dan 312. Dari data tersebut sehingga mengalami peningkatan keakuratan data penyandang disabilitas yang akan diberi pelayanan administrasi kependudukan. Hal yang bisa peneliti tarik dari hasil wawancara untuk indikator keuntungan relatif yaitu inovasi pelayanan "Laraku Nyata" merupakan inovasi yang memiliki banyak keuntungan dan dampak yang signifikan kepada pelaksana dan sasaran inovasi ini. Sesuai dengan teori yang telah disampaikan oleh Rogers dalam Basri (2018) yang telah dijelaskan sebelumnya. Sehingga inovasi "Laraku Nyata" telah memenuhi ciri atau atribut pertama yang menjadi syarat pembentukan inovasi pelayanan publik.

\section{Compability (Kesesuaian)}

Inovasi pelayanan publik yang dibentuk harus sesuai dengan apa yang dibutuhkan oleh sasaran inovasi pelayanan publik. Sesuai dengan teori Rogers, atribut atau ciri-ciri kedua dari inovasi pelayanan publik yaitu Compability (kesesuaian) diartikan sebagai inovasi mempunyai sifat kompatibel dan sesuai dengan inovasi yang digantinya agar inovasi sebelumnya tidak sia-sia. Hasil wawancara menunjukkan bahwa inovasi "Laraku Nyata" sudah sesuai dengan kebutuhan penyandang disabilitas yang ada di Kabupaten Bulukumba. Inovasi ini juga merupakan inovasi yang dibentuk untuk menghasilkan hal-hal baru bagi sistem-sistem pelayanan publik. Hasil yang diperoleh dari wawancara menunjukkan bahwa dari segi masyarakat penyandang disabilitas, inovasi tersebut sangat sesuai dengan kebutuhan penyandang disabilitas. Banyaknya penyandang disabilitas yang belum memiliki administrasi kependudukan sehingga kurang meratanyanya pelayanan dan bantuan yang diberikan oleh pemerintah. Dari inovasi ini, penyandang disabilitas dapat dijangkau dengan lebih banyak lagi dari sebelumnnya.

Hasil yang peneliti peroleh dari keseluruhan wawancara untuk indikator 
Compability (Kesesuaian) yaitu inovasi pelayanan "Laraku Nyata" sudah sesuai dengan apa yang dibutuhkan oleh penyandang disabilitas. Inovasi ini juga telah memenuhi standar pembaruan dengan tidak menimbulkan kesan inovasi lama tidak berguna tetapi memberikan nilai tambahan dan pembaruan untuk inovasi sebelumnya. Inovasi pelayanan publik sejatinya harus selalu ada pembaruan dengan tidak membuang sia-sia inovasi sebelumnya. Hal ini dikuatkan dengan data-data penyandang disabilitas yang semakin meningkat dari segi kepemilikan akta kelahiran, kartu keluarga, dan KTP. Data yang diperoleh dari tahun 2018-2020 menunjukkan penerbitan KTP, KK, semakin tahun menurun itu berarti bahwa sudah banyak masyarakat penyandang disabilitas yang teleh memiliki data kependudukan dan Adapun penerbitan yang dilakukan di tahun 2020 dan seterusnya merupakan penambahan dari penyandang disabilitas yang dijangkau seiring dengan pelaksanaan inovasi pelayanan publik "Laraku Nyata".

\section{Complexity (Kerumitan)}

Kerumitan ini diartikan dengan sifatnya yang baru, maka inovasi ini tentunya memiliki tingkat kerumitan yang kemudian bisa menjai hasil lebih tinggi dibandingkan dengan inovasi yang telah ada sebelumnya. Dalam penelitian ini kerumitan diartikan sebagai inovasi yang baru maka Dinas Kependudukan dan Pencatatan Sipil Kabupaten Bulukumba diharapkan mampu menerapkan inovasi pelayanan publik yang harus lebih baik dari sebelumnya walaupun dengan tingkat kerumitan yang tinggi. Berdasarkan hasil wawancara menunjukkan bahwa inovasi "Laraku Nyata" merupakan inovasi yang telah mampu memberikan pembaruan yang signifikan dari inovasi yang ada sebelumnya tanpa membuat inovasi sebelumnya sia-sia dilaksanakan. Inovasi "Laraku Nyata" dibentuk untuk menyempurnakan inovasi sebelumnya yang berkaitan dengan penyandang disabilitas. Inovasi ini berbentuk pelayanan publik kepada penyandang disabilitas yang sulit untuk dijangkau di inovasi sebelumnya sehingga "Laraku Nyata" hadir untuk melengkapi semua itu.

Cara pelaksanaanya ada dua cara yaitu menjemput langsung di kediaman penyandang disabilitas dan melakukan perekaman KTP di lokasi serta membantu penyandang disabilitas untuk mendapatkan bantuan dari Dinas Sosial. Adapun alur pelaksanaan pelayanan administrasi kependudukan bagi penyandang disabilitas yaitu yang pertama dilakukan pedataan oleh Dinas Sosial, kemudian data di verifikasi oleh Dinas Kependudukan dan Pencatatn Sipil melalui operator, kemudian dilakukan penjemputan dengan bantuan PMI dan PPDI, selanjutnya dilakukan perekaman Biometrik KTP-el di Dinas Kependudukan dan Pencatatan Sipil, lalu percetakan KTP-el, penyerahan dan terakhir purna layanan yang menghasilkan bantuan sosial berupa BPJS dan bantual lainnya dari Dinas Sosial. Sehingga indikator Complexity (Kerumitan) telah terpenuhi dalam inovasi pelayanan publik "Laraku Nyata" di lingkungan Dinas Kependudukan dan Pencatatan Sipil Kabupaten Bulukumba. Kerumitan yang dialami tinggi sehingga menghasilkan output yang lebih baik.

\section{Triability (Kemungkinan dicoba)}

Indikator Triability (Kemungkinan Dicoba) merupakan indikator keempat untuk ciri-ciri atau atribut inovasi pelayanan publik yang dikemukakan oleh Rogers. Triability (kemungkinan dicoba) merupakan inovasi yang hanya bisa diterima apabila teruji dan mampu terbukti keuntungan atau nilai lebih yang dihasilkan dibandingkan dengan inovasi lama. Kemungkinan dicoba dalam penelitian ini diartikan sebagai inovasi yang dilakukan harus melewati masa percobaan dan mampu memberikan pelayanan sebaik-baiknya kepada masyarakat dalam lingkup Dinas Kependudukan dan Pencatatan Sipil Kabupaten Bulukumba terkhusus bagi penyandang disabilitas. Untuk melihat hasil dari bagaimana "Laraku Nyata" telah melewati tahap keempat dalam pembentukan inovasi pelayanan publik maka telah dilakukan wawancara dan studi dokumentasi.

Adapun hasil wawancara menunjukkan bahwa inovasi "Laraku Nyata" merupakan kelanjutan dari inovasi sebelumnya, sehingga untuk kemungkinan dicoba sudah dilaksanakan. Selain itu sebelum pelaksanaanya Dinas Kependudukan dan Pencatatan Sipil Kabupaten Bulukumba telah melakukan sosialisasi mengenai inovasi pelayanan publik bagi penyandang disabilitas yang belum mempunyai 
administrasi kependudukan dalam hal ini "Laraku Nyata".

Dari sosialisasi yang dilakukan maka kemungkinan dicoba telah dilaksanakan, karena dengan sosialisasi tersebut maka dapat diketahui secara langsung kondisi lokasi, kebutuhan penyandang disabilitas, dan Langkah yang tepat dalam pengaplikasian inovasi "Laraku Nyata" serta dengan bantuan PPDI dapat mengetahui lebih dalam kebutuhan dan treatment khusus untuk memberikan pelayanan yang baik kepada seluruh penyandang disabilitas Kabupaten Bulukumba.

\section{Observability (Kemudahan)}

Indikator Observability (Kemudahan Diamati) merupakan indikator terakhir dari ciriciri atau atribut inovasi pelayanan publik yang dikemukakan oleh Rogers.

Observability menggambarkan bagaimana inovasi baru diciptakan bisa menghasilkan dampak lebih baik dan berjalan sesuai dengan harapan instansi selaku pencipta inovasi. Kemudahan diamati dalam penelitian ini berarti inovasi yang dibentuk untuk memberikan kemudahan bagi masyarakat dalam menerima pelayanan yang kemudian menjadi suatu tujuan diciptakannya inovasi pelayanan publik.

Dari hasil observasi dan wawancara dapat disimpulkan bahwa bahwa inovasi "Laraku Nyata" merupakan inovasi yang dengan mudah di amati hasilnya, baik secara langsung ataupun data-data yang diperoleh. Hal itu membuat Dinas Kependudukan dan Pencatatan Sipil Kabupaten Bulukumba berhasil membuat suatu inovasi yang baru demi kebutuhan pelayanan publik yang diharapkan oleh Dinas sebagai instansi terkait dan kepada penyandang disabilitas sebagai sasaran inovasi tersebut. kepuasan penyandang disabilitas dalam pelaksanaan inovasi "Laraku Nyata" ini sebagai bentuk pelayanan administrasi kependudukan bagi penyandang disabilitas. Hal itu sangat dengan mudah dilihat ataupun diamati dengan adanya bukti-bukti nyata berupa fasilitasfasilitas selain administrasi kependudukan yang diperoleh penyandang disabilitas.

\section{KESIMPULAN}

Berdasarkan hasil penelitian dan pembahasan, gambaran inovasi pelayanan laraku nyata ini diteliti dengan menggunakan teori dari Rogers yang terdiri dari 5 indikator atribut atau ciri-ciri inovasi pelayanan publik.

Maka dapat disimpulkan bahwa Inovasi pelayanan "Laraku Nyata" merupakan sebuah singkatan dari pelayanan identitas kependudukan bagi penyandang disabilitas. Inovasi ini dibentuk untuk menjangkau penyandang disabilitas yang belum memiliki data-data kependudukan. Kemudian telah mampu memberikan pelayanan yang sebaikbaiknya kepada penyandang disabilitas yang ada di Kabupaten Bulukumba, sehingga mereka mampu mendapatkan apa yang semestinya diperoleh dari pemerintah daerah seperti bantuan sosial.

Berdasarkan penelitian yang telah dilakukan didapatkan hasil bahwa inovasi pelayanan "Laraku Nyata" sangat memberikan dampak positif kepada penyandang disabilitas dengan banyaknya bantuan dan bimbingan yang diberikan. Juga memberikan dampak positif kepada Dinas Kependudukan dan Pencatatan Sipil Kabupaten Bulukumba dalam hal keakuratan Data penduduk yang ada di Kabupaten Bulukumba. Setelah analisis data dilakukan, menunjukkan gambaran pelaksanaan Inovasi "Laraku Nyata" dengan sebenarbenarnya yang ada di lapangan berdasarkan sumber data sekunder yang diperoleh melalui wawancara, observasi dan studi dokumentasi. Sehingga inovasi "Laraku Nyata" menjadi inovasi yang dapat dikategorikan berhasil dalam pelaksanaannya karena tidak adanya kekurangan yang didapatkan peneliti selama penelitian ini berlangsung.

\section{REFERENSI}

Anggraini, M.D. Dkk. (2017). Inovasi Pelayanan SAKINA di Puskesmas Sempu Kabupaten Banyuwangi. Jurnal E-SOSPOL, 6(2): 75-81.

Angraini, N dan Utomo, S.D. (2016). Inovasi Pelayanan Publik Bagi Disabilitas. Jakarta Selatan: Pattiro.

Anggraeny, Cindy. (2013). Inovasi Pelayanan Kesehatan dalam Meningkatkan Kualitas Pelayanan di Puskesmas Jagir Kota Surabaya. Jurnal Kebijakan dan Manajemen Publik, 1(1): 85-93.

Atthahara, Haura. (2018). Inovasi Pelayanan Publik Berbasis E-Government: Studi Kasus Aplikasi Ogan Lopian Dinas Komunikasi dan Informatika di 
Kabupaten Purwakarta. Jurnal Politikom Indonesiana, 3(1): 66-77.

Basri, Z. (2018). Inovasi Pelayanan Kesehatan Melalui Program Brigade Siaga Bencana (BSB) di Kabupaten Bantaeng. Universitas Hasanuddin, Makassar.

Cahyaningrum, A dan Nugroho, R.A. (2019). Inovasi Pelayanan melalui Aplikasi "Dukcapil dalam Genggaman" oleh Dinas Kependudukan dan Pencatatan Sipil Kota Surakarta. Jurnar Administrasi Publik, 7(2): 103-115.

Djumara. Dkk. (2009). Standar Pelayanan Publik. Jakarta: Pusat Kajian Manajemen Pelayanan LAN.

Irwanto, Dkk. (2010). Analisis Situasi Penyandang Disabilitas di Indonesia: Sebuah Desk-Review. Pusat Kajian Disabilitas. Fakultas Ilmu Sosial dan Ilmu Politik Universitas Indonesia, Depok.

Kurniawan, Cahyadi. R. (2016). Inovasi Kualitas Pelayanan Publik Pemerintah Daerah. Jurnal Fiat Justisia, 10(3): 569-586.

Lestari, Dkk. (2017). Pemenuhan Hak Bagi Penyandang Disabilitas di Kabupaten Semarang Melalui Implementasi Convention On The Rights Of Persons With Disabilities (CPRD) Dalam Bidang Pendidikan. Jurnal Integralistik, 27(1): 1-9.

Lupiyoadi, Rambat. (2001). Manajemen Pemasaran Jasa, Edisi Pertama: Tepri dan Praktik. Jakarta: Salemba Empat.

Nurdin, Ismail. (2019). Kualitas Pelayanan Publik. Surabaya: Sahabat Cendekia.

Pebriani, V dan Rohman, Abd. (2019). Analisis Inovasi Pelayanan Publik Gesit Aktif Merakyatnya Dinas Kependudukan dan Pencatatan Sipil (GAMPI) Kota Malang. Jurnal Ilmu Sosial dan Ilmu Politik, 8(1): 122-128.

Sellang, Kamaruddin. (2016). Administrasi dan Pelayanan Publik Antara Teori dan Aplikasinya. Yogyakarta: Ombak.

Sugiyono. (2017). Metode Penelitian Kuantitatif, Kualitatif dan $R \& D$. Bandung: Alfabeta.

Sururi, Ahmad. (2017). Inovasi Kebijakan dalam Perspektif Administrasi Publik Menuju Terwujudnya Good Publik
Policy Governance. Jurnal Spirit Publik, 12(2): 14-31.

Taufiqurokhman dan Satispi, Evi. (2018). Teori dan Perkembangan Manajemen Pelayanan Publik. Tangerang Selatan: UMJ Press.

Tahir, Muchlas dan Harakan, Ahmad. (2017). Inovasi Program Kesehatan 24 Jam dalam Mewujudkan Good Health Care Governance di Kabupaten Bantaeng. Jurnal Imiah, 2(1): 13-22. 